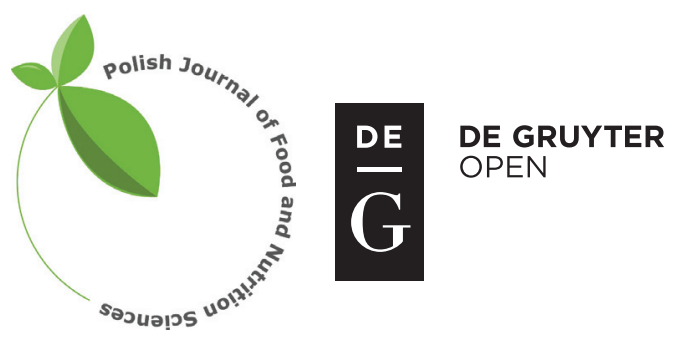

Pol. J. Food Nutr. Sci., 2017, Vol. 67, No. 3, pp. 173-181

DOI: $10.1515 /$ pjfns-2016-0032 http://journal.pan.olsztyn.pl

Review article

Section: Food Quality and Functionality

\title{
Composition and Biological Properties of Agaricus bisporus Fruiting Bodies - a Review
}

\author{
Bożena Muszyńska ${ }^{1, *}$, Katarzyna Kata ${ }^{1}$, Jacek Rojowski ${ }^{2}$, Agata Grzywacz, Wtodzimierz Opoka ${ }^{2}$ \\ 'Department of Pharmaceutical Botany, Faculty of Pharmacy, Jagiellonian University Medical College, \\ Medyczna 9 St., 30-688 Cracow, Poland \\ ${ }^{2}$ Department of Inorganic and Analytical Chemistry, Faculty of Pharmacy, \\ Jagiellonian University Medical College, Medyczna 9 St., 30-688 Cracow, Poland
}

Key words: Agaricus bisporus, bioactive metabolites, cultivated mushrooms, edible mushrooms, ergothioneine

White Agaricus bisporus is both the most popular and the most commonly eaten edible mushroom species in the world. It is popular not only because of its taste, but also due to its high level of nutrients: dietary fiber (chitin), essential, semi-essential amino acids, unsaturated fatty acids including linoleic and linolenic acids, easily digestible proteins, sterols, phenolic and indole compounds, and vitamins - especially provitamin $\mathrm{D}_{2}$ and $\mathrm{B}_{1}, \mathrm{~B}_{2}, \mathrm{~B}_{6}$, $\mathrm{B}_{7}$, and $\mathrm{C}$. Fruiting bodies of A. bisporus have antioxidant, antibacterial, anti-inflammatory, antitumor, and immunomodulatory activity. The presence of antioxidant ergothioneine (which also displays the antimutagenic, chemo- and radioprotective activity) is also noteworthy. A. bisporus also contains derivatives of benzoquinone, a substance which belongs to the group of antibiotics. Studies of tyrosinase isolated from this species show its very high similarity to human tyrosinase. This points directly to the fact that this species could be a rich source of tyrosinase used for medicinal and cosmetics purposes. A. bisporus is also a rich source of selenium, zinc and other elements such as magnesium, copper, iron, potassium, sodium, calcium, phosphorus, sulfur or manganese. In conclusion, the presence of these compounds and elements with biological activity in fruiting bodies of $A$. bisporus confirms their nutraceutical and medicinal properties.

\section{INTRODUCTION}

Mushrooms have a scientifically confirmed beneficial influence on human health. This property stretches beyond that which can be expected from nutrients found in mushrooms. Based upon the chemical composition of edible mushroom fruiting bodies, it can be stated that they are a valuable source of dietary ingredients necessary for stimulating the development and growth of the human organism and sustaining its life functions. Agaricus bisporus (J.E. Lange) Imbach - white or button mushroom, is mainly available for consumers from commercial cultures; it is well known for its taste and aroma. The most important qualities of $A$. bisporus are its dietetic and medicinal properties derived from its rich composition of metabolites and biologically-active elements. A. bisporus is a rich source of dietary fiber (chitin), essential and semi-essential amino acids, and antioxidant substances (sterols, phenolic and indole compounds, ergothioneine, vitamins, selenium) [Elmastas et al., 2007; Foulongne-Orio et al., 2013].

A. bisporus grows in Poland between May and September. Usually, it occurs in places fertilized with cow dung, compost piles, parks and forests. Its growth on open spaces is rare. More frequently, it can be cultivated on special culturing substrates [Leiva et al., 2015]. A. bisporus plays an important part

\footnotetext{
* Corresponding Author: E-mail: muchon@poczta.fm (B. Muszyńska) amino acids as $70.55 \mathrm{mg} / \mathrm{g}$ dry weight (D.W.). Arginine pres-

in the decomposition of leaves and needles in parks and forests. Apart from its ecological function, it is one of the most frequently cultivated mushrooms worldwide. The first known information about $A$. bisporus culturing comes from France in 1707 [Elmastas et al., 2007; Foulongne-Orio et al., 2013; Glamočlija et al., 2015] and for this reason, the species is also widely known as the Paris champignon.

The aim of the present study was to describe the importance, dietary value, and medicinal properties of A. bisporus fruiting bodies.

\section{THE MAIN GROUPS OF BIOLOGICALLY-ACTIVE SUBSTANCES IN AGARICUS BISPORUS}

\section{Amino acids in fruiting bodies of Agaricus bisporus}

Fruiting bodies of $A$. bisporus are a rich source of amino acids (essential, semi-essential, and non-essential). Eighteen of these compounds were researched and described, but some are not present in sufficiently high amounts to make A. bisporus a source for supplementation. The amino acids found in A. bisporus in the highest amounts are alanine, aspartic acid, glutamic acid, arginine, leucine, lysine, phenylalanine, serine, proline, tyrosine and threonine [Bernaś et al., 2006a; Muszyńska et al., 2013a]. On the other hand, cysteine, methionine and valine are the least abundant [Bernaś et al. 2006b]. Liu et al. [2013] determined the total content of free 
ent in the Agaricales taxon should be given special attention - because it is a component used in dietary supplements for patients with cancer. Arginine delays tumor growth and metastasis, and also has a beneficial influence on the immunological system, body mass growth and the life-expectancy of oncological patients [Novaes et al., 2011]. In further research, it was shown that the processes of production and storage (the most popular are drying, preserving in air tight containers, salting and freezing) of $A$. bisporus decrease the total content of amino acids in this species. The decrease in amino acid concentrations after six months of storage ranged between $40 \%$ and $90 \%$ and depended on the processing method [Bernaś et al., 2006b]. Pei et al. [2014] determined free amino acids in fruiting bodies of $A$. bisporus and their content ranged from 0.8 to $14.1 \mathrm{mg} / \mathrm{g}$ D.W. The total content of free amino acids was up to $44.2 \mathrm{mg} / \mathrm{g}$ D.W. [Pei et al., 2014]. The detailed information is to be found in Table 1.

\section{Saccharides in Agaricus bisporus fruiting bodies}

Mushrooms are characterized by high contents of monosaccharides, disaccharides and polysaccharides. Research has shown that the total content of carbohydrates in fruiting bodies of white mushroom ranges between 4.5 and $4.6 \%$ of fresh weight or 51.3 and $62.5 \%$ dry weight (Table 1). A. bisporus is also a rich source of fiber which beneficially affects the digestive tract. Although the cell walls of plants are usually considered a main source of dietary fiber - mushrooms can also assume this function. Mushroom cell walls contain a mixture of fibers and matrix components that are rich in chitin (a crosslinked polymer of $\mathrm{N}$-acetylglucosamine) and other polysaccharides such as $\beta$-D-glucans and mannans [Cheung, 2013; Liu et al., 2013]. Apart from its role in the metabolism, dietary fiber from mushrooms plays an important role in the regulation of lipid levels, and decreasing levels of low density lipoprotein (LDL) and total cholesterol without interfering with high density lipoprotein concentrations (HDL) [Cheung, 2013; Muszyńska et al., 2013a; Rajewska \& Bałasinska, 2004]. The mechanism of this phenomenon is not entirely clear, but it has been proven that the fiber from mushrooms can be an alternative to that originating from other foodstuffs. A hypocholesterolemic effect can be caused by impaired absorption in the digestive tract due to dietary fiber presence, or by the influence of intestinal or pancreatic secretion. Other possible mechanisms include an indirect influence on lipoproteins or the bile acid metabolism. Considering a high content of dietary fiber and a low content of fat, A. bisporus may become a dietary component that prevents atherosclerosis [Fukushima et al., 2000]. Chitin and chitosan are commonly used in the pharmaceutical industry. Apart from being adjuvant in many drugs, these substances are ingredients of many slimming preparations. The slimming effect occurs due to decreased absorption of lipids from food. The efficacy of chitosan was researched with two groups of volunteers on a low fat diet. Patients regularly taking chitosan reduced their weight considerably more quicker. The chitosan group lost, on average, $7 \mathrm{~kg}$ and the patients from the control group lost only $3 \mathrm{~kg}$ [Rajewska \& Bałasińska, 2004]. Apart from a beneficial influence on fat metabolism and body weight decrease, the research also showed an improvement in sugar metabo- lism. Consumption of A. bisporus caused a $24.7 \%$ decrease in glucose levels in type II diabetic rats. A similar positive effect was obtained in rats with hypercholesterolemia, in which a decrease in LDL and total cholesterol was noted as well as an increase in HDL cholesterol fraction [Czapski, 2005; Jeong et al., 2010].

Apart from their antimicrobial activity, chitin and chitosan are also used in wound dressings. Their action involves local pain relief (due to separating pain receptors from environmental exposure), wound healing enhancement and prevention of scaring [Rajewska \& Bałasinska, 2004]. An important property of chitosan - its blood clotting ability - has been used in hemorrhaging wound dressings. Chitosan can work without setting up a normal blood clotting cascade. Unfortunately, its effectiveness has been questioned due to its low adhesion abilities. New animal trials suggest that modified chitosan with higher bioadhesive abilities will be significantly more effective in wound treatment [De Castro et al., 2012]. Currently, dressings based on chitosan are used in military medicine - even for very severe combat injuries. Chitosan-based dressings were used by the US army during the Iraqi intervention. There have been promising results from new experiments into the use of chitosan in dental surgery where parts of military dressings were used for hemorrhages during teeth extraction [Bennett \& Littlejohn, 2014; Malmquist et al., 2008].

Trehalose, a disaccharide found in A. bisporus (with the content ranging from $1 \%$ to $3 \%$ D.W.), is metabolized to glucose in the human organism. It stimulates enzymes responsible for the stabilization of protein structures during chemical and thermal denaturation. In mushrooms, trehalose acts as a carbohydrate reservoir and protects the mushroom from extreme environmental conditions such as temperatures, osmotic stress or radiation. Mushrooms are also rich in sugar alcohols such as mannitol (5-30\% D.W.) [Gheibi et al., 2006; Malmquist et al., 2008; Wannet et al., 1998]. Pei et al. [2014] found the content of mannitol in fresh fruiting bodies at $121 \mathrm{mg} / \mathrm{g}$ and that for trehalose at $12.1 \mathrm{mg} / \mathrm{g}$. These researchers examined whether the freeze drying influenced the level of these compounds and found decreased contents of these sugars after the freeze drying process.

Fucogalactan from A. bisporus (EFP-Ab) presented a new class of mushroom metabolites with anti-inflammatory activity as a result of suppressed iNOS and COX-2 expression [Ruthes et al., 2013].

A. bisporus contains a linear $(1 \rightarrow 6)-\beta$-d-glucan that can be isolated by DMSO extraction. This compound inhibits the expression of pro-inflammatory genes and reduces LPS-induced inflammation by inhibition of IL-1 and COX-2 proteins [Smiderle et al., 2013].

\section{Lectins from fruiting bodies of $\boldsymbol{A}$. bisporus and their antiproliferative activity}

Lectins are the next group of therapeutically-active compounds found in A. bisporus fruiting bodies and mycelium from in vitro cultures. Lectins are conjugates of proteins (mainly storage proteins) and saccharides produced by mushrooms and plants. It has been proven that the role of lectins is more complicated in mushrooms than in plants [Hassan 
et al., 2015]. These substances are involved in numerous processes on a molecular and cell level. In higher mushroom species such as the white mushroom, lectins may play various roles depending on growth phase or environmental conditions. Lectins are storage proteins intervening in growth, development and morphogenesis phases. Some are involved in important functions of mushroom metabolism such as mycorrhiza or parasitic dependencies with other organisms. Lectins may protect the mushrooms from toxins coming from the environment, such as pesticides or bacteria [Ng, 2004]. Lectins, particularly those from edible mushrooms, have attracted the attention of the academic community, because their immunomodulatory activity comes from an acceleration of immunological cell maturation and a potential anticancer activity. The anticancer effect is possible due to the anti-proliferative influence of lectins of $A$. bisporus (ABL) on endothelial carcinoma cells, without inducing the cytotoxic effect [Carrizo et al., 2005; Singh et al., 2015]. Lectins from A. bisporus are also capable of inhibiting the reverse transcriptase of HIV1, which stops virus replication in host cells [Wang $\& \mathrm{Ng}, 2001]$. ABL have been researched as active compounds in psoriasis (because it is a disease originating from excessive proliferation of human keratocytes) [Yu et al., 1999]. Application of lectins stops further cell divisions without any cytotoxic effect on endothelium cells [Parslew et al., 1999]. Lectins have also been examined as active in vitreoretinopathy and other eye diseases involving wound healing impairment. The ABL slow retina contractions and adhesion of human pigmentation cells to retina endothelium, also without any cytotoxic effect. During clinical trials, lectins have shown strong antiproliferative action against epithelial cells of the retina, which could directly reduce retinal detachment [Kent et al., 2003ab; Wang et al., 2012]. The ABL show the anti-proliferative action towards numerous types of cells. One in vitro experiment was conducted to confirm the inhibitory effect of ABL on fibroblasts found in the Tennon capsule. An increase in wound healing was shown, which furthermore led to the application of $\mathrm{ABL}$ in controlling scaring after surgical glaucoma treatment [Batterbury et al., 2002]. Lectins have also been examined as potentially anti-diabetic substances effective both in prophylaxis and treatment. This effect comes from lectins capability to enhance the divisions of $\beta$ cells in pancreatic islets. Some studies have been performed to determine the degree of regeneration on $\beta$ cells in mice and to describe the mechanisms of their proliferation. The analysis was conducted based on glucose measurements and insulin secretion levels after administration of mushroom lectins. It was shown that lectins from A. bisporus decreased blood glucose levels [Ahmad et al., 1984; Jeong et al., 2010].

\section{Indole compounds in fruiting bodies of Agaricus bisporus}

Recent research has proven that A. bisporus contains non-hallucinogenic indole compounds [Muszyńska et al., $2015 \mathrm{a}, \mathrm{b}]$. Indole compounds have a beneficial influence on the human organism and play an important role in numerous metabolic pathways - as neurotransmitters or their precursors. Indoles are important compounds due to their anti-cancer and anti-aging activity; these compounds regulate cell cycles and blood clotting. The pharmacological profile of these compounds also includes their antioxidant activity. The fruiting bodies of $A$. bisporus contain L-tryptophan, 5-hydroxy-L-tryptophan, melatonin, serotonin, tryptamine, and 5-methyl-tryptamine [Muszyńska et al., 2013b]. The research conducted by Muszyńska describes the amount of indole compounds extracted from A. bisporus to artificial gastric juice. This research showed how much of each indole compound is released from white mushroom fruiting bodies or in vitro cultures in the conditions of the human digestive tract. The fruiting bodies were obtained from a commercial source and the in vitro cultures from liquid cultures on Oddoux medium (both standard and enriched in zinc hydroaspartate). Four indole compounds were identified and assayed: 5-hydroxy-L-tryptophan, L-tryptophan, serotonin, and 5-methyl-tryptamine. A. bisporus could be a good source of indole compounds [Muszyńska et al., 2015a, b]. The contents of indole compounds in fruiting bodies range from 0.06 to $6.21 \mathrm{mg} / 100 \mathrm{~g} \mathrm{D}$.W. (Table1). The highest content has been reported for kynurenic acid [Muszyńska et al., 2011].

\section{Phenolic compounds in fruiting bodies of Agaricus bisporus}

Phenolic acids are the major representatives of the phenol compounds present in mushrooms. They exhibit a wide spectrum of biological activities which have been attributed to their strong antioxidant activity and ability to protect vital cellular structures, such as cell membranes, and also structural proteins, enzymes, membrane lipids or nucleic acids. Gallic, caffeic, ferulic, $p$-coumaric, and protocatechuic acids are found in fruiting bodies of A. bisporus. They are characterized by antioxidant, antibacterial, antiviral, antifungal, anti-inflammatory, and gastric-secretion stimulatory actions, documented by in vitro and in vivo studies [Czapski, 2005; Labus et al., 2011; Liu et al., 2013]. In addition, protocatechuic acid has been shown to possess immunomodulating, spasmolytic, cardioprotectant, anticoagulant, and chemopreventive properties [Wee, 2010]. The contents of phenolic compounds in fruiting bodies of $A$. bisporus range from $2.31 \mathrm{mg} / \mathrm{kg} \mathrm{D.W}$. for $p$-coumaric acid to $2729 \mathrm{mg} / \mathrm{kg} \mathrm{D.W}$. for myricetin [Czapski, 2005; Labus et al., 2011; Liu et al., 2013]. A positive correlation between microbial inhibitions and the total content of phenolic compounds in ethanol extracts from fruiting bodies of $A$. bisporus was presented in an Australian research [Ndungutse et al., 2015]. The content of phenolic compounds in A. bisporus fruiting bodies is presented in Table 1.

\section{Tyrosinase from fruiting bodies of Agaricus bisporus and its properties}

The pharmacological properties and application of white mushrooms are connected with the process of melanogenesis in the human organism. Melanogenesis - the biosynthesis of the pigment melanin in the skin - is catalyzed by tyrosinase. Since the discovery of this enzyme, research has been undertaken in order to find a good natural source of this substance. It has been found that $A$. bisporus naturally contains large quantities of this compound. Tyrosinase acts as a catalyst in the hydroxylation of monophenol and the oxi- 
dation of diphenol in the presence of atmospheric oxygen [Kampmann et al., 2015; Labus et al., 2011; Zaidi et al., 2014]. It has also been shown that tyrosinase isolated from A. bisporus may catalyze bisphenol reactions, which could make this species a useful bioremediation agent [Kampmann et al., 2015]. Tyrosinase plays an important role in the synthesis of melanin in melanocytes found in epidermis and cells from the neural crest. This enzyme was described for the first time in mammals [Bloch, 1927]. Its connection with the development of melanoma has been described, as well as its link to skin pigmentation problems (such as vitiligo or albinism) [Zaidi et al., 2014]. Tyrosinase can be extracted from various sources, i.e. mushrooms and fruits. In mushrooms, melanin is involved in numerous defense mechanisms that protect mushrooms from various stress factors such as UV or gamma radiation, free radicals, dehydration or extreme temperatures. The stability of mushroom spores is also derived from the protective action of melanin. Furthermore, tyrosinase has a role in wound healing and immunological response in plants. In humans, tyrosinase is involved in melanocyte pigmentation processes; it is also a marker in melanoma patients and takes part in the prodrug metabolism [Labus et al., 2011; Zaidi et al., 2014]. Research on tyrosinase isolated from white mushrooms has shown a high similarity to human tyrosinase. It suggests that this species could be a rich source of tyrosinase for medicinal and cosmetic purposes [Labus et al., 2011; Zaidi et al., 2014]. Tyrosinase is a thermolabile protein. It shows a protective effect towards Raji cells (human lymphoma cell line), preventing oxidative DNA damage. A. bisporus species shows a protective effect to DNA isolated from lymphocytes taken from rats into which mushroom extracts have been injected intraperitoneally. The genoprotective effect of tyrosinase has been determined by gel electrophoresis of single cells and cell damage extent after application of stress generating factors was evaluated. In the test, enzymatic hydroxylation of tyrosine occurred, leading to levodopa and then a conversion to dopaquinone. The protective potential of oxidative damage depends on tyrosinase, which is a first link in the tyrosine reaction pathway. This is not an effect of oxidant inactivation but levodopa conversion, which is possible due to the catalytic action of A. bisporus tyrosinase [Shi et al., 2002].

\section{Ergothioneine in fruiting bodies of Agaricus bisporus and their antioxidant activity}

The antioxidant action of $A$. bisporus is connected with a histidine derivative - ergothioneine. Ergothioneine is a water-soluble compound found in some mycobacteria and molds and it is not synthesized by animals, in which it is important for proper functioning. These organisms easily absorb ergothioneine and store it in cells that are especially susceptible to oxidative stress. The highest amount of this substance can be found in erythrocytes, the eye lens, semen, and skin. Its most important feature is the ability to reduce lesions due to irradiation, hypoxia (from transplantations), heart attack or brain stroke. Ergothioneine is a key substrate for organic cation transporters (OCTN1) and plays a protective role for monocytes. A decreased level of these cells and their improper differentiation is characteristic for auto-immunological diseases such as rheumatoid arthritis or Crohn's disease. Apart from its antioxidant action, ergothioneine also shows antimutagenic, chemo- and radioprotective activity, which makes it an important medical substance [Chen et al., 2012; Muszyńska et al., 2013a]. The content of ergothioneine found in fruiting bodies of $A$. bisporus by Dubost et al. [2007] was at $0.21 \mathrm{mg} / \mathrm{g}$ D.W. Chen et al. [2012] stated that the content of this compound was higher and reached up to $0.93 \mathrm{mg} / \mathrm{g}$ D.W. These data show that $A$. bisporus is one of the best sources of this compound [Chen et al., 2012].

\section{Fruiting bodies of $\boldsymbol{A}$. bisporus as a source of lovastain}

One of the most significant compounds found in fruiting bodies of $A$. bisporus is lovastatin -- an approved-to-market drug used in the treatment of hypercholesterolemia -- that acts as an inhibitor of HMG-CoA reductase. The highest content of lovastatin $(565.4 \mathrm{mg} / \mathrm{kg} \mathrm{D.W}$.) has been found in fruiting bodies of mature mushrooms [Chen et al., 2012].

\section{Fruiting bodies of $\boldsymbol{A}$. bisporus as a source of agaritine}

Agaritine has been claimed to be a weak carcinogen. It was shown to induce adenomas and adenocarcinomas in the lungs and to cause bladder and stomach cancer in mice [Kondo et al., 2008]. Agaritine content decreases during preservation. Storage at $5^{\circ} \mathrm{C}$ reduced its content to $25 \%$ and $50 \%$ after 6 and 14 days, respectively [Schulzová et al., 2002]. However, this compound displays the antiviral activity, e.g. as a potent inhibitor of HIV protease [Sorimachi \& Koge, 2008].

\section{Fruiting bodies of Agaricus bisporus as a source of vitamins}

White mushroom is a rich source of vitamins, especially the $\mathrm{B}$-group vitamins $\left(\mathrm{B}_{1}, \mathrm{~B}_{2}, \mathrm{~B}_{3}\right.$, niacin, folates, $\left.\mathrm{B}_{12}\right)$, and vitamin $\mathrm{D}_{2}$ - provitamin ergosterol, and ergocalciferol [Kalbarczyk \& Radzki, 2009]. This species is also a good source of vitamin C (17 mg/100 g D.W.) [Bernaś et al., 2006b; Kalbarczyk $\&$ Radzki, 2009]. The content of vitamins varies depending on mushroom growing conditions (including environmental factors). A. bisporus contains ergosterol - a precursor of vitamin $\mathrm{D}_{2}$ (ergocalciferol) which is necessary for sustaining the appropriate calcium-phosphate balance in the human organism. Ergosterol content in fruiting bodies of $A$. bisporus is usually reported to range from $61.5 \mathrm{mg} / 100 \mathrm{~g}$ of D.W. [Muszyńska et al., 2013a] to $186.1 \mathrm{mg} / 100 \mathrm{~g}$ D.W. [Heleno et al., 2016]. The high levels of this substance make white mushroom a rich source of vitamin D for vegetarians and vegans [Muszyńska et al., 2013a]. There have been experiments designed to enrich $A$. bisporus with vitamin $\mathrm{D}_{2}$ via irradiation with UV-B and UV-C light [Koyalamudi et al., 2009; Roberts et al., 2008]. Their results seem to be promising in the prevention of common vitamin D deficiencies, including in Poland. Detailed information about the content of vitamins in fruiting bodies of $A$. bisporus is presented in Table 1.

\section{Fruiting bodies of $\boldsymbol{A}$. bisporus as a source of macro- and microelements}

The fact that mushrooms are able to accumulate elements from the environment explains their attractiveness for researchers. Bioelements that are absorbed by some mushroom species 
TABLE 1. Content of biologically-active substances in A. bisporus fruiting bodies.

\begin{tabular}{|c|c|c|c|}
\hline Group & Examples & Content & Reference \\
\hline 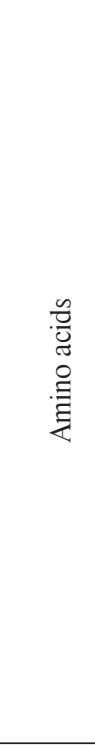 & $\begin{array}{c}\text { Total amino acids } \\
\text { Lysine } \\
\text { Threonine } \\
\text { Valine } \\
\text { Methionine } \\
\text { Isoleucine } \\
\text { Leucine } \\
\text { Phenylalanine } \\
\text { Arginine } \\
\text { Glycine } \\
\text { Histidine } \\
\text { Asparagine acid } \\
\text { Glutamate acid } \\
\text { Serine }\end{array}$ & $\begin{array}{c}\text { (mg/g D.W.) } \\
44.2 \\
3.5 \\
1.3 \\
2.3 \\
0.8 \\
1.0 \\
0.8 \\
2.1 \\
2.2 \\
2.0 \\
14.1 \\
3.4 \\
5.6 \\
3.1 \\
\text { (g/100 g total } \\
\text { proteins in F.W.) } \\
1.1 \\
4.2 \\
5.8 \\
6.1\end{array}$ & $\begin{array}{c}\text { [Bernaś et al., } \\
\text { 2006b] } \\
\text { [Pei et al., 2014] }\end{array}$ \\
\hline 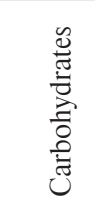 & $\begin{array}{l}\text { Total sugar } \\
\text { Fructose } \\
\text { Mannitol } \\
\text { Trehalose }\end{array}$ & $\begin{array}{c}\text { (g/100 g F.W.) } \\
4.50 \\
2.62 \\
23.62 \\
(\% / D . W .) \\
1-3\end{array}$ & $\begin{array}{l}\text { [Gheibi et al., } \\
\text { 2006] } \\
\text { [Kalbarczyk \& } \\
\text { Radzki, 2009] }\end{array}$ \\
\hline 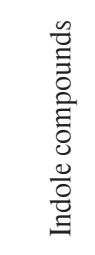 & $\begin{array}{l}\text { L-Tryptophan } \\
\text { Serotonin } \\
\text { Melatonin } \\
\text { Tryptamine } \\
\text { Kynurenic acid } \\
\text { Indoloacetic acid }\end{array}$ & $\begin{array}{c}\text { (mg/100 g D.W.) } \\
0.39 \\
5.21 \\
0.11 \\
0.06 \\
6.21 \\
0.19\end{array}$ & $\begin{array}{l}\text { [Muszyńska } \\
\text { et al., 2011] }\end{array}$ \\
\hline 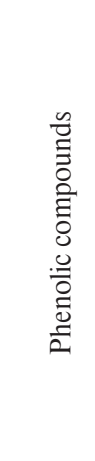 & $\begin{array}{c}\text { Gallic acid } \\
\text { Procatechuic acid } \\
\text { Catechins } \\
\text { Caffeic acid } \\
\text { Ferulic acid } \\
\text { Myricetin } \\
\text { p-Coumaric acid } \\
\text { Cinnamic acid }\end{array}$ & $\begin{array}{c}\text { (mg/kg D.W.) } \\
176-487 \\
277-687 \\
\\
\text { (mg/kg D.W.) } \\
280.45 \\
83.26 \\
56.74 \\
392.51 \\
42.83 \\
2729.46 \\
2.31 \\
0.38 \mathrm{mg} / \mathrm{kg} \text { D.W. }\end{array}$ & $\begin{array}{l}\text { [Czapski, 2005] } \\
\text { [Labus et al., } \\
\quad \text { 2011] } \\
\text { [Liu et al., 2013] } \\
\text { [Reis et al., 2012] }\end{array}$ \\
\hline
\end{tabular}

act as enzyme activators or are their structural parts. The most important mechanism of accumulation of elements in mushrooms is based on binding by metallothionein - a low-molecular-weight protein, which has an affinity especially for metals. Elements can also be found in mushroom dyes. Numerous researchers have also confirmed the presence of copper, magnesium, iron, sodium, potassium, calcium, phosphorus, zinc, lithium, titanium, barium, strontium, selenium, cadmium, lead, chromium, and nickel. The content of these elements is shown in Table 1. White mushroom is a rich source of selenium and zinc. These elements demonstrate antioxidant abilities, due to which mushrooms can prevent oxidation of unsaturated fatty acids. Selenium levels can be as high as $0.5 \mathrm{mg} / 100 \mathrm{~g} \mathrm{D.W}$. [Falandysz \& Borovička, 2013; Yilmaz et al., 2006]. Zinc is vital

\begin{tabular}{|c|c|c|c|}
\hline Group & Examples & Content & Reference \\
\hline 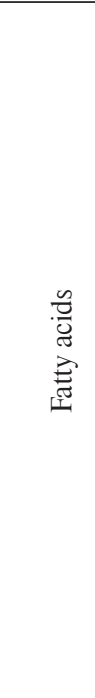 & $\begin{array}{c}\text { Total lipids } \\
\text { Caprylic acid } \\
\text { Caprinic acid } \\
\text { Laurnic acid } \\
\text { Miristic acid } \\
\text { Pentadecanoic } \\
\text { acid } \\
\text { Palmitynic acid } \\
\text { Palmitoleic acid } \\
\text { Stearic acid } \\
\text { Oleic acid } \\
\text { Linoleic acid } \\
\text { Linolenic acid } \\
\text { Arachidic acid } \\
\text { Total saturated } \\
\text { fatty acids } \\
\text { Total unsaturated } \\
\text { fatty acids }\end{array}$ & $\begin{array}{c}\mathrm{mg} / 100 \mathrm{~g} \text { D.W. } \\
2.7 \\
(\%) \\
1.08 \\
0.85 \\
0.11 \\
0.94 \\
0.23 \\
\\
13.35 \\
4.84 \\
3.72 \\
6.07 \\
67.29 \\
1.52 \\
0.92 \\
20.28 \\
\\
79.72\end{array}$ & $\begin{array}{l}\text { [Öztürk et al., } \\
\text { 2011] }\end{array}$ \\
\hline$\stackrel{\mathscr{\Xi}}{\stackrel{\Xi}{\Xi}}$ & $\begin{array}{c}\text { Vitamin } C \\
\text { Vitamin } B_{1} \\
\text { Vitamin } B_{2} \\
\text { Vitamin } B_{3} \\
\text { Niacin } \\
\text { Folic acid } \\
\text { Vitamin } \\
B_{12} \text { Vitamin D }\end{array}$ & $\begin{array}{c}\text { (mg/100 g D.W.) } \\
17.0 \\
0.6 \\
5.1 \\
43.0 \\
42.0 \\
(\mu \mathrm{g} / 100 \mathrm{~g} \text { D.W. }) \\
450 \\
0.8 \\
3.0\end{array}$ & $\begin{array}{c}\text { [Bernaś et al., } \\
\text { 2006b] } \\
\text { [Kalbarczyk \& } \\
\text { Radzki, 2009] }\end{array}$ \\
\hline $\begin{array}{l}\overline{0} \\
\stackrel{0}{0} \\
\overline{0} \\
0 \\
0 \\
0\end{array}$ & $\begin{array}{l}\alpha \text {-Tocopherol } \\
\gamma \text {-Tocopherol } \\
\delta \text {-Tocopherol }\end{array}$ & $\begin{array}{c}(\mathrm{mg} / 100 \mathrm{~g}) \\
1-4 \\
2-3 \\
1\end{array}$ & [Tsai et al., 2008] \\
\hline $\begin{array}{l}\frac{n}{0} \\
\frac{0}{\infty} \\
\ddot{n}\end{array}$ & $\begin{array}{c}\text { Ergosterol } \\
\text { Ergosta-7-enol } \\
\text { Ergosta-5,7- } \\
\text {-dienol } \\
\text { Ergosta-7,22- } \\
\text {-dienol }\end{array}$ & $\begin{array}{c}\mathrm{mg} / 100 \mathrm{~g} \text { D.W. }) \\
186.1 \\
1.73 \\
6.05 \\
\\
2.45\end{array}$ & $\begin{array}{c}\text { [Heleno et al., } \\
\text { 2016] } \\
\text { [Muszyńska } \\
\text { et al., 2013a] }\end{array}$ \\
\hline 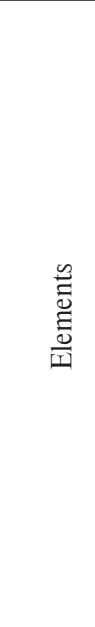 & $\begin{array}{c}\text { Copper } \\
\text { Magnesium } \\
\text { Iron } \\
\text { Sodium } \\
\text { Potassium } \\
\text { Calcium } \\
\text { Phosphorus } \\
\text { Zinc } \\
\text { Lithium } \\
\text { Titanium } \\
\text { Barium } \\
\text { Strontium } \\
\text { Selenium } \\
\text { Cadmium } \\
\text { Lead } \\
\text { Chromium } \\
\text { Nickel }\end{array}$ & $\begin{array}{c}\text { (mg/kg D.W.) } \\
25-125 \\
1150.5-2275 \\
200-400 \\
760-860 \\
35000-45200 \\
460-990 \\
9690-17300 \\
54.81-112.75 \\
17.1-36.9 \\
5.00-15.5 \\
2.06-7.71 \\
0.015-0.037 \\
0.053-0.150 \\
0.021-0.091 \\
0.028-0.148 \\
0.344-0.640 \\
0.101-0.778\end{array}$ & $\begin{array}{c}\text { [Bernaś et al., } \\
\text { 2006b] } \\
\text { [Kalać, 2010] } \\
\text { [Kalembasa } \\
\text { et al., 2012] } \\
\text { [Muszyńska } \\
\text { et al., 2015b] }\end{array}$ \\
\hline
\end{tabular}

D.W. - dry weight, F.W. fresh weight.

for protein synthesis, an important component of digestive enzymes, and is involved in insulin storage and in the activation of more than 300 enzymes. According to the literature data, 
zinc content in fruiting bodies of Agaricus species ranges from 7.5 to $15 \mathrm{mg} / 100 \mathrm{~g}$ D.W. [Kalač, 2010]. The daily requirement for this element in a healthy adult human is dependent on age and is about $15 \mathrm{mg}$ [Johnson, 2003]. The levels of zinc released from fruiting bodies and biomass from in vitro cultures of $A$. bisporus have been established. A maximum of $2 \mathrm{mg} \mathrm{Zn/100} \mathrm{g}$ D.W. are released from fruiting bodies of $A$. bisporus to artificial digestive juices, whereas the total amount of zinc released from biomass of $A$. bisporus obtained from in vitro culture averages $10 \mathrm{mg} / 100 \mathrm{~g}$ D.W. The highest total concentration of this element released into artificial digestive juices has been found in biomass of $A$. bisporus cultures on the culture medium with the addition of $200 \mathrm{mg} / \mathrm{L}$ zinc hydroaspartate (up to 57 mg/100 g D.W.) [Muszyńska et al., 2015a]. The levels of elements in extracts of fruiting bodies of $A$. bisporus are presented in Table 1.

\section{BIOLOGICAL ACTIVITY OF FRUITING BODIES OF AGARICUS BISPORUS}

\section{Anti-carcinogenic and antioxidant properties of substances found in fruiting bodies of $A$. bisporus}

Free radicals usually found in the human organism can lead to the development of many civilization diseases, such as cancer or cardiovascular disease. Oxidative stress and free radical production can be caused by diseases, long periods of stress or natural aging. There are internal natural mechanisms in the human organism that can prevent oxidative stress, such as the production of free radical species - superoxide dismutase (SOD) or catalase [Elmastas et al., 2007; Hu et al., 2015; Maseko et al., 2014; Tsai et al., 2008]. These natural mechanisms should be aided by providing antioxidants with food. As a source of antioxidants, A. bisporus has for many years been examined for the potential preventive action in hypertension, hypercholesterolemia or cancer [Elmastas et al., 2007; Tsai et al., 2008]. Due to their acetylcholinesterase and butyrylcholinesterase inhibiting activity, A. bisporus extracts can be potentially applied in Alzheimer's disease treatment [Öztürk et al., 2011].

Apart from its occurrence in the natural environment, white mushroom is widely grown on organic substrates. Methanol extracts from this species have been examined for antioxidant activity derived from high concentrations of $\alpha$-tocopherol and these have also revealed the presence of $\beta$-carotene [Tsai et al., 2008]. The antioxidant effect of A. bisporus is strongly correlated with substances found in this mushroom that act as reducers in many chemical reactions, and that are able to scavenge free radicals or chelate metal ions [Elmastas et al., 2007; Glamočlija et al., 2015; Vamanu \& Nita, 2014]. The role of $A$. bisporus fruiting body extracts in the prevention of some cancer types such as breast cancer or prostate cancer has been researched and confirmed. The main substances responsible for this action are phenol compounds, lectins, $\beta$-glucans, arginine, ergothioneine and fatty acids (80\% of total fatty acid amount are unsaturated fatty acids). This is important, because a deficiency in these substances in the diet can be the causative agent of many diseases, such as cancer or circulatory system diseases [Ahmad et al., 2013; Novaes et al., 2011; Öztürk et al., 2011; Patel \& Goyal, 2012; Yilmaz et al., 2006].
A. bisporus is a rich source of fatty acids such as palmitic acid, linoleic acid, linolenic acid that can prevent the development of breast cancer [Öztürk et al., 2011]. This action involves inhibition of aromatase and consequently - synthesis of estrogens - hormones that play an important role in breast cancer development. The latest clinical research has shown that aromatase inhibitors are effective in hormone-dependent mammary cancer treatment [Patel \& Goyal, 2012; Chen et al., 2006]. In research conducted by Chen et al. [2006], A. bisporus extracts were the most effective aromatase inhibitors, when compared with seven other plant extracts. Phenolic acids isolated from A. bisporus, including hydroxybenzoic acid and protocatechuic acid, are also characteristic for this species. These substances, apart from their typical anti-carcinogenic activity, also show antioxidant and anti-inflammatory actions [Siwulski et al., 2014]. The application of $A$. bisporus to anticancer therapy should, therefore, be feasible and inexpensive [Chen et al., 2006].

The anti-carcinogenic activity can also be observed for ergosterol found in the Agaricales taxon. This can provide anti-carcinogenic activity via inhibiting the metaplastic cell migration and proliferation. Ergosterol can also inhibit angiogenesis. In patients treated with ergosterol, a delay in tumor growth has been obtained along with minimal side effects. In patients under chemotherapy, extracts rich in ergosterol did not induce any adverse effects on the level of lymphocytes [Novaes et al., 2011].

\section{Antimicrobial and antiviral activity of Agaricus bisporus}

The ethanolic extract of fruiting bodies of A. bisporus contains various components with antimicrobial activity. The freeze-dried extract of this species displays activity towards Escherichia coli CBAB 2 (Minimum Inhibitory Concentration - MIC - $5 \mathrm{mg} / \mathrm{mL}$ ), and also against Staphylococcus aureus ATCC 6588 (Gram negative). On the other hand, Pseudomonas aeruginosa ATCC 15442 has proved to be the most resistant strain, with a MIC value of $15 \mathrm{mg} / \mathrm{mL}$ [Vamanu, 2012].

The antimicrobial action of numerous mushroom species (including A. bisporus) is due to high contents of chitosan and chitin. Chitin and its deacetylated derivative - chitosan, are polysaccharides whose molecular weight is relatively high (similar to the ones found in crustaceans), which could suggest that their antibacterial properties are reduced. The antimicrobial effect of chitin and its derivatives increases with a decrease in the molecular weight. The activity is based on decreasing bacterial adhesion to the culture medium [Rajewska et al., 2004]. Research into Agaricus campestris, a species closely related to $A$. bisporus, has shown the presence of agarodoxin - a benzoquinone derivate. This substance is an antibiotic and shows activity against Staphylococcus aureus (golden staph) [Muszyńska et al., 2011]. A. bisporus, on the other hand, shows activity against Micrococcus luteus, Micrococcus flavus, Bacillus subtilis, Bacillus cereus, Candida albicans, and Candida tropicalis [Öztürk et al., 2011].

\section{CONCLUSION}

The fruiting bodies of Agaricus bisporus, which is one of the most commonly cultivated and consumed mushrooms, are a good source of many substances with biological 
activity. Because of its ability to accumulate physiologicallyactive compounds, metals and vitamins, $A$. bisporus is not only a very popular delicacy but also an effective additive for the human diet. Due to high contents of bioelements and organic compounds essential for humans, its fruiting bodies consumption provides a high nutritional value. A. bisporus also contains substances that are well known for decreasing blood sugar levels and changing lipid profiles. Additionally, it has anti-carcinogenic, antioxidant, antibacterial, and antiviral properties. Determination of ergothioneine and tyrosinase in fruiting bodies has partially explained their activities and has made this species a significant mushroom with a medical and nutritional value.

Until today, numerous researches have been conducted in a model of the human digestive tract. These experiments showed that the fruiting bodies and biomass of in vitro cultures of $A$. bisporus release physiologically-active substances to artificial digestive juices. The next stage of research should be to determine the absorption level of the examined compounds which were previously released to artificial digestive juices. For this reason, our future research will address the precise determination of released substances and establishing the percent in which these physiologically-active compounds are absorbed by passive and active transport.

\section{RESEARCH FUNDING}

This study was supported by a Jagiellonian University Medical College project (No. K/ZDS/005619).

\section{CONFLICT OF INTEREST}

Authors declare no conflict of interest.

\section{REFERENCES}

1. Ahmad N., Bansal R., Rastogi A.K., Kidwai J.R., Effect of PHA-B fraction of Agaricus bisporus lectin on insulin release and $45 \mathrm{Ca}^{2+}$ uptake by islets of Langerhans in vitro. Acta Diabetol. Lat., 1984, 21, 63-70.

2. Ahmad M.S., Ahmad S., Gautam B., Afzal M., Antigenotoxic and anticlastogenic potential of Agaricus bisporus against MMS induced toxicity in human lymphocyte cultures and in bone marrow cells of mice. Egypt. J. Med. Hum. Genet., 2013, 14, 395-402.

3. Batterbury M., Tebbs C.A., Rhodes J.M., Grierson I., Agaricus bisporus (Edible Mushroom Lectin) inhibits ocular fibroblast proliferation and collagen lattice contraction. Exp. Eye Res., 2002, 74, 361-370.

4. Bennett B.L., Littlejohn L., Review of new topical hemostatic dressings for combat casualty care. Mil. Med., 2014, 179, 497-514.

5. Bernaś E., Jaworska G., Kmiecik W., Storage and processing of edible mushrooms. Acta Sci. Pol. Technol. Aliment., 2006a, $5,5-23$.

6. Bernaś E., Jaworska G., Lisiewska Z., Edible mushrooms as a source of valuable nutritive constituents. Acta Sci. Pol. Technol. Aliment., 2006b, 5, 5-20.
7. Bloch B., In Handbuch der Haut- und Geschlechtskrankheiten. Herausgegeben. 1927, Von J. Jadassohn, Springer, Berlin, pp. 434-541.

8. Carrizo M.E., Capaldi S., Perduca M., Irazoqui F.J., Nores G.A., Monaco H.L., The antineoplastic lectin of the common edible mushroom (Agaricus bisporus) has two binding sites, each specific for a different configuration at a single epimeric hydroxyl. J. Biol. Chem., 2005, 280, 10614-10623.

9. Chen S., Oh S.R., Phun S., Hur G., Ye J.J., Kwok S.L., Shrode G.E., Belury M., Adams L.S., Williams D., Anti-aromatase activity of phytochemicals in white button mushrooms (Agaricus bisporus). Cancer. Res., 2006, 66, 12026-12034.

10. Chen Y.C., Ho K., Hsieh Y., Wang T., Mau J., Contents of lovastatin, $\gamma$-aminobutyric acid and ergothioneine in mushroom fruiting bodies and mycelia. LWT - Food Sci. Technol., 2012, 47, 274-278.

11. Cheung P.C.K., Mini-review on edible mushrooms as source of dietary fiber: Preparation and health benefits. Food Sci. Human Wellness, 2013, 2, 162-166.

12. Czapski J., Antioxidant activity and phenolic content in some strains of mushrooms (Agaricus bisporus). Veg. Crop. Res., 2005, 62, 165-173.

13. De Castro G.P., Dowling M.B., Kilbourne M., Keledjian K., Driscoll I.R., Raghavan S.R., Hess J.R., Scalea T.M., Bochicchio G.V., Determination of efficacy of novel modified chitosan sponge dressing in a lethal arterial injury model in swine. J. Trauma Acute Care Surg., 2012, 72, 899-907.

14. Dubost N.J., Ou B., Beelman R.B., Quantification of polyphenols and ergothioneine in cultivated mushrooms and correlation to total antioxidant capacity. Food Chem., 2007,105, 727-735.

15. Elmastas M., Isildak O., Turkekul I., Temur N., Determination of antioxidant activity and antioxidant compounds in wild edible mushrooms. J. Food Compos. Anal., 2007, 20, 337-345.

16. Falandysz J., Borovička J., Macro and trace mineral constituents and radionuclides in mushrooms: health benefits and risk. Appl. Microbiol. Biotechnol., 2013, 97, 477-501.

17. Foulongne-Orio M., Murat C., Castanera R., Ramírez L., Sonnenberg A.D.W., Genome-wide survey of repetitive DNA elements in the button mushroom Agaricus bisporus. Fungal Genet. Biol., 2013, 55, 6-21.

18. Fukushima M., Nakano M., Morii Y., Ohashi T., Fujiwara Y., Sonoyama K., Hepatic LDL receptor mRNA in rats is increased by dietary mushroom (Agaricus bisporus) fiber and sugar beet fiber. J. Nutr., 2000, 130, 2151-2156.

19. Gheibi N., Saboury A.A., Haghbeen K., Moosavi-Movahedi A.A., The effect of some osmolytes on the activity and stability of mushroom tyrosinase. J. Biosci., 2006, 31, 355-362.

20. Glamočlija J., Stojković D., Nikolić M., Ćirić A., Reis F.S., Barros L., Ferreira I.C.F.R., A comparative study on edible mushrooms as functional foods. Food Funct., 2015, 6, 1900-1910.

21. Hassan M.A.A., Rouf R., Tiralongo E., May T.W., Tiralongo J., Mushroom lectins: specificity, structure and bioactivity relevant to human disease. Int. J. Mol. Sci., 2015 16, 7802-7838.

22. Heleno S.A., Diz P., Prieto M.A., Barros L., Rodrigues A., Barreiro M.F., Frerriera I.C.F.R., Optimization of ultrasound-assisted extraction to obtain mycosterols from Agaricus bisporus L. by response surface methodology and comparison with conventional Soxhlet extraction. Food Chem., 2016, 197, 1054-1063. 
23. Hu Y.H., Chen C.M., Xu L., Cui Y., Yu X.Y., Gao H.J., Wang Q., Liu K., Shi Y., Chen Q.X., Postharvest application of 4-methoxy cinnamic acid for extending the shelf life of mushroom (Agaricus bisporus). Postharvest Biol. Tec., 2015, 104, 33-41.

24. Jeong S.C., Jeong Y.T., Yang B.K., Islam R., Koyyalamudi S.R., Pang G., Cho K.Y., Song C.H., White button mushroom (Agaricus bisporus) lowers blood glucose and cholesterol levels in diabetic and hypercholesterolemic rats. Nutr. Res., 2010, 30, 49-56.

25. Johnson M.A., Encyclopedia of Food Sciences and Nutrition. 2003, The University of Georgia, Athens, GA, USA (Second Edition).

26. Kalač P., Trace element contents in European species of wild growing edible mushrooms: A review for the period 2000-2009. Food Chem., 2010, 122, 2-15.

27. Kalbarczyk J., Radzki W., Cultivated mushrooms as a valuable diet constituent and a source of biologically active substances. Herba Pol., 2009, 55, 224-232 (in Polish).

28. Kalembasa D., Becher M., Rzymowski D., Some trace elements and heavy metals content in substrate, cover and mushroom Agaricus bisporus. Ochrona Środowiska i Zasobów Naturalnych, 2012, 52, 86-92 (in Polish).

29. Kampmann M., Hoffrichter A.C., Stalinski D., Wichmann R., Kinetic characterization of tyrosinase containing mushroom (Agaricus bisporus) cells immobilized in silica alginate. J. Mol. Catal. B: Enzym., 2015, 116, 124-133.

30. Kent D., Sheridan C.M., Tomkinson H.A., White S.J., Hiscott P., Grierson I., Edible mushroom (Agaricus bisporus) lectin modulates human retinal pigment epithelial cell behavior in vitro. Exp. Eye Res., 2003a, 76, 213-219.

31. Kent D., Sheridan C.M., Tomkinson H.A., White S.J., Hiscott P., Yu L., Grierson I., Edible mushroom (Agaricus bisporus) lectin inhibits human retinal pigment epithelial cell proliferation in vitro. Wound Repair Regen., 2003b, 11, 285-291.

32. Kondo K., Watanabe A., Akiyama H., Maitani T., The metabolisms of agaritine, a mushroom hydrazine in mice. Food Chem. Toxicol., 2008, 46, 854-862.

33. Koyalamudi S.R., Jeong S.C., Song C.H., Cho K.Y., Pang G., Vitamin $\mathrm{D}_{2}$ formation and bioavailability from Agaricus bisporus button mushrooms treated with ultraviolet irradiation. J. Agric. Food Chem., 2009, 57, 3351-3355.

34. Labus K., Turek A., Liesiene J., Bryjak J., Efficient Agaricus bisporus tyrosinase immobilization on cellulose-based carriers. Biochem. Eng. J., 2011, 56, 232-240.

35. Leiva F.J., Saenz-Díez J.C., Martínez E., Blanco J., Environmental impact of Agaricus bisporus cultivation process. Eur. J. Agron., 2015, 71, 141-148.

36. Liu J., Jia L., Kan J., Jin C.H., In vitro and in vivo antioxidant activity of ethanolic extract of white button mushroom (Agaricus bisporus). Food Chem. Toxicol., 2013, 51, 310-316.

37. Malmquist J.P., Clemens S.C., Oien H.J., Wilson S.L., Hemostasis of oral surgery wounds with the hemcon dental dressing. J. Oral Maxillofac. Surg., 2008, 66, 1177-1183.

38. Maseko T., Howell K., Dunshea F.R., Ng K., Selenium-enriched Agaricus bisporus increases expression and activity of glutathione peroxidase-1 and expression of glutathione peroxidase-2 in rat colon. Food Chem., 2014, 146, 327-333.

39. Muszyńska B., Sułkowska-Ziaja K., Ekiert H., Indole compounds in fruiting bodies of some edible Basidiomycota species. Food Chem., 2011, 125, 1306-1308.
40. Muszyńska B., Sułkowska-Ziaja K., Łojewski M., Opoka W., Zając M., Rojowski J., Edible mushrooms in prophylaxis and treatment of human diseases. Med. Inter. Rev., 2013a, 101, 170-183.

41. Muszyńska B., Sułkowska-Ziaja K., Wójcik A., Levels of physiologically active indole derivatives in the fruiting bodies of some edible mushrooms (Basidiomycota) before and after thermal processing. Mycoscience, 2013b, 54, 321-326.

42. Muszyńska B., Kała K., Sułkowska-Ziaja K., Gaweł K., Zając M., Opoka W., Determination of indole compounds released from selected edible mushrooms and their biomass to artificial stomach juice. LWT - Food Sci. Technol., 2015a, 62, 27-31.

43. Muszyńska B., Smalec A., Sułkowska-Ziaja K., Opoka W., Reczyński W, Baś B., Culinary-medicinal Agaricus bisporus (white button mushroom) and its in vitro cultures as a source of selected biologically-active elements. J. Food Sci. Tech., 2015b, 52, 7337-7344.

44. Ng T.B., Peptides and proteins from fungi. Peptides, 2004, 25, 1055-1073.

45. Ndungutse V., Mereddy R., Sultanbawa Y., Bioactive properties of mushroom (Agaricus bisporus) stipe extracts. J. Food Process. Preserv., 2015, 39, 2225-2233.

46. Novaes M.R., Valadares F., Reis M.C., Gonçalves D.R., Menezes M.C., The effects of dietary supplementation with Agaricales mushrooms and other medicinal fungi on breast cancer: evidence-based medicine. Clinics (Sao Paulo), 2011, 66, 2133-2139.

47. Öztürk M., Duru M.E., Kivrak S., Mercan-Doğan N., Türkoglu A., Özler M.A., In vitro antioxidant, anticholinesterase and antimicrobial activity studies on three Agaricus species with fatty acid compositions and iron contents: A comparative study on the three most edible mushrooms. Food Chem. Toxicol., 2011, 49, 1353-1360.

48. Patel S., Goyal A., Recent developments in mushrooms as anticancer therapeutics: a review. 3 Biotech., 2012, 2, 1-15.

49. Parslew R., Jones K.T., Rhodes J.M., Sharpe G.R., The antiproliferative effect of lectin from the edible mushroom (Agaricus bisporus) on human keratinocytes: preliminary studies on its use in psoriasis. Brit. J. Dermatol., 1999, 140, 56-60.

50. Pei F., Shi Y., Gao X., Wu F., Mariga M.A., Yanh W., Zhao L., An X., Xin Z., Yang F., Hu Q., Changes in non-volatile taste components of button mushroom (Agaricus bisporus) during different stages of freeze drying and freeze drying combined with microwave vacuum drying. Food Chem., 2014, 165, 547-554.

51. Rajewska J., Bałasińska B., Biologically active compounds of edible mushrooms and their beneficial impact on health. Postepy Hig. Med. Dosw., 2004, 58, 352-357 (in Polish).

52. Reis F.S., Martins A., Barros L., Ferreira I.C., Antioxidant properties and phenolic profile of the most widely appreciated cultivated mushrooms: a comparative study between in vivo and in vitro. Food Chem. Toxicol., 2012, 50, 1201-1207.

53. Roberts J., Teichert A. McHugh T.H., Vitamin $\mathrm{D}_{2}$ formation from post-harvest UV-B treatment of mushrooms (Agaricus bisporus) and retention during storage. J. Agric. Food Chem., 2008, 56, $4541-4544$.

54. Ruthes A.C., Rattmann Y.D., Malquevicz-Paiva S.M., Baggio C.H., Santos A.R.S., Gorin P.A.J., Iacomin M., Agaricus bisporus fucogalactan: Structural characterization and pharmacological approaches. Carbohydr. Polym., 2013, 92, 184-191. 
55. Shi Y.L., Benzie I.F., Buswell J.A., Role of tyrosinase in the genoprotective effect of the edible mushroom, Agaricus bisporus. Life Sci., 2002, 70, 1595-1608.

56. Schulzová V., Hajšlová J., Peroutka R., Gry J., Andersson H.C., Influence of storage and house hold processing on the agaritine content of the cultivated Agaricus mushroom. Food Addit. Contam., 2002, 19, 853-862.

57. Singh S.S., Wang H., Chan Y.S., Pan W., Dan X., Yin C.M., Akkouh O., Ng T.B., Lectins from edible mushrooms. Molecules, 2015, 20, 446-469.

58. Siwulski M., Sobieralski K., Sas-Golak I., Nutritive and healthpromoting value of mushrooms. Żywn. Nauka Technol. Jakość, 2014, 1, 16-28 (in Polish).

59. Smiderle F.R., Alquini G., Tadra-Sfeir M.Z., Iacomini M., Wichers H.J., Van Griensven L.J.L.D., Agaricus bisporus and Agaricus brasiliensis $(1 \rightarrow 6)$ - $\beta$-d-glucans show immunostimulatory activity on human THP-1 derived macrophages. Carbohydr. Polym., 2013, 94, 91-99.

60. Sorimachi K., Koge T., Agaricus blazei water extracts as alternative medicines. Curr. Pharm. Anal., 2008, 4, 39-43.

61. Tsai S.Y., Wu T.P., Huang S.J., Mau J.L., Antioxidant properties of ethanolic extracts from culinary-medicinal button mushroom Agaricus bisporus (J. Lange) Imbach (Agaricomycetes) harvested at different stages of maturity. Int J. Med. Mushrooms, 2008, $10,127-137$.

62. Vamanu E., Determination of antioxidant and antimicrobial properties of Agaricus bisporus from Romanian markets. 2012, Ovidius University Annals of Chemistry, Constanta, Romania, pp. 47-52.

63. Vamanu E., Nita S., Biological activity of fluidized bed ethanol extracts from several edible mushrooms. Food Sci. Biotechnol., 2014, 23, 1483-1490.
64. Wang Y., Liu Y., Wang H., Li C., Qi P., Bao J., Agaricus bisporus lectins mediates islet $\beta$-cell proliferation through regulation of cell cycle proteins. Exp. Biol. Med., 2012, 237, 287-296.

65. Wang H.X., Ng T.B., Examination of lectins, polysaccharopeptide, polysaccharide, alkaloid, coumarin and trypsin inhibitors for inhibitory activity against human immunodeficiency virus reverse transcriptase and glycohydrolases. Planta Med., 2001, 67, 669-672.

66. Wannet W.J.B., Op den Camp H.J.M.O, Wisselink H.W., Van der Drift C., Van Griensven L.J.L.D., Vogels G.D., Purification and characterization of trehalose phosphorylase from the commercial mushroom Agaricus bisporus. Biochim. Biophys. Acta, 1998, 1425, 177-188.

67. Wee J.J., Identification of anticoagulant components in Korean red ginseng. J. Ginseng Res., 2010, 34, 355-362.

68. Yilmaz N., Solmaz M., Türkekul İ., Elmastaş M., Fatty acids composition in some wild edible mushrooms growing in the middle Black Sea region of Turkey. Food Chem., 2006, 99, 168-174.

69. Yu L.G., Fernig D.G., White M.R., Spiller D.G., Appleton P., Evans R.C., Grierson I., Smith J.A., Davies H., Gerasimenko O.V., Petersen O.H., Milton J.D., Rhodes J.M., Edible mushroom (Agaricus bisporus) lectin, which reversibly inhibits epithelial cell proliferation, blocks nuclear localization sequence-dependent nuclear protein import. J. Biol. Chem., 1999, 19, 4890-4899.

70. Zaidi K.U., Ali A.S., Ali S.A., Purification and characterization of melanogenic enzyme tyrosinase from button mushroom. Enzyme Res., 2014, ID 120739.

Submitted: 24 December 2015. Revised: 31 May, 13 June, and 26 August 2016. Accepted: 20 September 2016. Published online: 21 November 2016. 
